Chapman University

Chapman University Digital Commons

Food Science Faculty Articles and Research

Science and Technology Faculty Articles and

Research

6-20-2018

\title{
Species Substitution and Country of Origin Mislabeling of Catfish Products on the U.S. Commercial Market
}

\author{
Shayna A. Bosko \\ Chapman University \\ Denise M. Foley \\ Santiago Canyon College \\ Rosalee S. Hellberg \\ Chapman University, hellberg@chapman.edu
}

Follow this and additional works at: https://digitalcommons.chapman.edu/food_science_articles

Part of the Aquaculture and Fisheries Commons, Food Processing Commons, Other Animal $\underline{\text { Sciences Commons, and the Other Food Science Commons }}$

\section{Recommended Citation}

Bosko SA, Foley DM, Hellberg RS. 2018. Species substitution and country of origin mislabeling of catfish products on the U.S. commercial market. Aquaculture 495:715-720. DOI: 10.1016/j.aquaculture.2018.06.052

This Article is brought to you for free and open access by the Science and Technology Faculty Articles and Research at Chapman University Digital Commons. It has been accepted for inclusion in Food Science Faculty Articles and Research by an authorized administrator of Chapman University

Digital Commons. For more information, please contact laughtin@chapman.edu. 


\title{
Species Substitution and Country of Origin Mislabeling of Catfish Products on the U.S. Commercial Market
}

\author{
Comments \\ NOTICE: this is the author's version of a work that was accepted for publication in Aquaculture. Changes \\ resulting from the publishing process, such as peer review, editing, corrections, structural formatting, and \\ other quality control mechanisms may not be reflected in this document. Changes may have been made to this \\ work since it was submitted for publication. A definitive version was subsequently published in Aquaculture, \\ volume 495, in 2018. DOI: 10.1016/j.aquaculture.2018.06.052 \\ The Creative Commons license below applies only to this version of the article.
}

\section{Creative Commons License}

\section{(c) 10 (1)}

This work is licensed under a Creative Commons Attribution-Noncommercial-No Derivative Works 4.0 License.

\section{Copyright}

Elsevier 
1 Species substitution and country of origin mislabeling of catfish products on the U.S.

2 commercial market

3 Shayna A. Bosko ${ }^{\mathrm{a}}$, Denise M. Foley ${ }^{\mathrm{b}}$, Rosalee S. Hellberg ${ }^{\mathrm{a} *}$,

4

$5 \quad$ aChapman University, Schmid College of Science and Technology, Food Science and Nutrition,

61 University Drive, Orange, CA 92866

7

8 bSantiago Canyon College, Department of Biology,

98045 E Chapman Avenue, Orange, CA 92869

10

11 *Corresponding Author

12 Rosalee S. Hellberg, Ph.D.

13 Chapman University

14 Phone: 1-714-628-2811

15 E-mail: hellberg@chapman.edu

16

17

18

19

20

21 


\section{Abstract}

23 Catfish belong to the order Siluriformes and include both the Ictaluridae and Pangasiidae

24 families. However, U.S. labeling laws require only species of the family Ictaluridae to be 25 marketed as catfish. The lower production price of Pangasiidae, combined with changes in 26 regulations over time, have resulted in high potential for species substitution and country of

27 origin mislabeling among catfish products. The objective of this study was to conduct a market 28 survey of catfish products sold at the U.S. retail level to examine species mislabeling and 29 compliance with Country of Origin Labeling (COOL) regulations. A total of 80 catfish samples 30 were collected from restaurants, grocery stores and fish markets in Orange County, CA. DNA

31 was extracted from each sample and tested with real-time polymerase chain reaction (PCR) using 32 the InstantID ${ }^{\mathrm{TM}}$ U.S. Catfish Assay Kit for Ictaluridae spp. (InstantLabs). Samples that tested 33 negative for Ictaluridae were tested with real-time PCR using the using the InstantID Asian 34 Catfish Assay Kit for Pangasiidae spp. DNA barcoding was used as a final test in cases where 35 species could not be identified with either of the real-time PCR assays. Overall, 7 of the 80 of the 36 catfish products were found to be substituted with Pangasiidae species for a mislabeling rate of $379 \%$. This included five of the 40 restaurant samples and two of the 32 grocery store samples. 38 Additionally, 59\% of grocery store samples were not compliant with COOL regulations. The 39 results of this study reveal the occurrence of catfish mislabeling on the U.S. commercial market and suggest the need for continuous monitoring of these products.

42 Keywords: Catfish; DNA barcoding; Pangasius; real-time PCR; seafood fraud; country of origin 


\section{Introduction}

Fisheries and aquaculture are an important source of food, nutrition, and income for

45 hundreds of millions of people globally. In 2014, the world per capita fish supply reached a new 46 high of $20 \mathrm{~kg}$, attributed to the expanding growth in aquaculture which is responsible for half of 47 all fish for human consumption (FAO 2016). In the United States, over $90 \%$ of the seafood is 48 imported with over half of imports coming from aquaculture (NOAA 2016a). With this high 49 percentage of foreign trade, an increase in seafood processing and consumer demand, and 50 globalization of the seafood industry, the potential for seafood fraud increases (Hellberg and 51 Morrissey 2011). Fish in their whole, unprocessed form are generally identifiable by

52 morphological indicators. However, following processing it can be difficult to identify a species 53 by conventional taxonomic means. Seafood fraud, such as species substitution and mislabeling, 54 can occur at any stage along the supply chain from the initial production/capture to retail shops 55 and restaurants. In the case of seafood substitution, a low-valued species is typically substituted 56 for a more expensive one while other types of seafood mislabeling, such as inaccurate country of 57 origin labeling, are committed to evade inspection, tariffs, and other costs (NOAA 2016a).

58 Accurate labeling of seafood is necessary to ensure food safety, avoid economic, social, and 59 conservation concerns, and truthfully inform consumers (Naaum et al. 2016).

60 Country of Origin Labeling (COOL) is a labeling law that requires large retailers, such as 61 supermarkets, to provide information regarding method of production and country of origin 62 (Country of Origin Labeling for Fish and Shellfish, 7 C.F.R. § 60, 2009). COOL for covered fish 63 and shellfish commodities became effective in 2005 and is regulated by the USDA's Agricultural 64 Marketing Service (AMS). As part of COOL, fresh or frozen fish that have not undergone 65 transformation or processing outlined in 7 C.F.R. $\S 60$ must be labeled with the name of the 
country the fish is from and the method of production (wild-caught or farm-raised) (AMS 2017a). Wild-caught fish are those that are naturally-born or hatchery-originated that are released in the wild and caught from non-controlled waters, while farm-raised fish are harvested in controlled environments. Although food service establishments and fish markets may voluntarily include this information on the label, they are exempt from this ruling as they are not defined as retailers under the Perishable Agriculture Commodities Act (1930; AMS 2017a). Similarly, processed food items that have undergone specific processing resulting in a change in the character of the commodity (e.g., cooked or smoked catfish) or those that have been combined with at least one other covered commodity or food component (e.g., breaded catfish) are not subject to COOL. However, unless excepted by law, foreign articles imported into the United States must be labeled with the correct country of origin according to 19 C.F.R. § 134.11 (Country of Origin Marking, 2011).

Catfish, order Siluriformes, represent more than 3,000 species, 477 genera, and 36 families (Ferraris 2007). In the U.S., the most commonly consumed species of Siluriformes are from the Ictaluridae and Pangasiidae families (Delaware Sea Grant 2017). Ictaluridae catfish, including blue catfish (Ictalurus furcatus) and channel catfish (Ictalurus punctatus), are the leading aquaculture-produced seafood in the U.S., generating approximately half the freshwater aquaculture value in 2014 (NOAA 2016b). Ictaluridae catfish are also farm-raised in other countries and imported into the United States, largely from China (NOAA 2018). Pangasius catfish are part of the Pangasiidae family and include swai (Pangasianodon hypophthalmus; also known as tra or sutchi) and basa (Pangasius bocourti). These freshwater fish are primarily found in the wild in South Asia and Southeast Asia and are farm-raised in a number of countries, including Vietnam (Delaware Sea Grant 2017). Pangasius fish have been experiencing steady 
89 demand globally, with the United States being the largest import market (FAO 2016). Vietnam

90 was the main source of imported Pangasius in the United States in 2016, with other sources

91 being Thailand and China (NOAA 2018). Pangasius fish are relatively low-priced (FAO 2016);

92 for example, one of the Southern California supermarket chains included in the current study

93 advertised prices of US $\$ 4.99 / \mathrm{lb}$ ( $\$ 11.00 / \mathrm{kg})$ for swai and US $\$ 8.99 / \mathrm{lb}(\$ 19.82 / \mathrm{kg})$ for U.S. catfish

94 in April 2018.

Vietnam began exporting Pangasius to the United States after the embargo on trade with

Vietnam was lifted in 1994 and exports grew tremendously following the removal of tariffs on

97 raw seafood in 1999 (Duc 2010). Swai and basa were initially marketed as “catfish” by

distributors in the U.S. However, with increasing competition from Vietnamese catfish imports,

99 the Association of Catfish Farmers of America (CFA) campaigned to require that Vietnamese catfish be labeled as basa or swai to differentiate them from American catfish (Brambilla et al.

101 2012). In 2002, U.S. Congress passed a labeling law restricting the use of the name "catfish" 102 only to the Ictaluridae family (Duc 2010; Brambilla et al. 2012). These labeling restrictions were 103 incorporated into the United States Code under the Farm Security and Rural Investment Act 104 (2002). However, passage of the labeling law did not lead to a significant recovery in U.S. 105 catfish prices, and CFA filed an antidumping lawsuit against Vietnam. In 2003, anti-dumping 106 duties were placed on imports of frozen swai and basa from Vietnam (DOC 2003). Since 2003, 107 several individuals and companies have been convicted of criminal charges related to falsely 108 mislabeling Vietnamese Pangasius as other species, such as grouper or sole, to avoid these tariffs 109 (DOJ 2009; 2010; 2011). Although most seafood is subject to periodic inspection by the U.S. Food and Drug 111 Administration (FDA), catfish are subject to continuous inspection by the United States 
112 Department of Agriculture (USDA) Food Safety Inspection Services (FSIS) under the Federal

113 Meat Inspection Act (FMIA), as required by the 2014 U.S. Farm Bill (FSIS 2015). The final

114 ruling released by FSIS regarding the catfish inspection program became effective in March

115 2016, with an 18-month transitional period until full enforcement in September 2017. According

116 to the 2014 Farm Bill, catfish subject to continuous inspection include all "fish of the order

117 Siluriformes.” FSIS inspection procedures under the FMIA include verification that appropriate

118 food safety standards and humane handling requirements are being followed. As part of the

119 catfish inspection program, lab samples may be periodically collected for analysis of chemical

120 residues, Salmonella, or speciation (FSIS 2018).

121 Existing literature on seafood fraud is extensive. Numerous studies have inspected the

122 mislabeling of various types of fish including salmon, tilapia, grouper, halibut, and pollock.

123 However, there is limited research specific to catfish mislabeling. In a market survey conducted

124 by Consumer Reports, 3 of 21 "catfish” products purchased at retail outlets and restaurants in the

125 Northeastern United States were identified as swai with DNA testing (Consumer Reports 2011).

126 In a 2012 survey of seafood labeling at the wholesale distribution level, the FDA performed

127 DNA barcoding on 40 fillets from 5 lots of domestic, channel catfish in California and reported

128 that none of the samples was mislabeled (FDA 2012). On the contrary, in a study conducted in

129 the Southeastern U.S., Wang and Hsieh (2016) reported that 26.7\% of 15 "catfish" menu items

130 purchased from at restaurants were identified as Pangasius. According to the study authors,

131 Pangasius has the potential to be substituted for Ictalurus spp. because it is rapidly grown,

132 produces a higher yield, and commands a lower price (Wang and Hsieh 2016). In a review of

133 seafood fraud reported globally, Pangasius was found to be one of the most commonly

134 substituted fish and was mislabeled as 18 different types of higher-valued species (Warner et al. 
2016).

Due to the potential for catfish products to be mislabeled on the U.S. commercial market, the overall objective of this study was to investigate rates of species substitution and COOL compliance for catfish products sold at the retail level. Through a combination of real-time PCR and DNA barcoding, catfish products sold within the U.S. were analyzed to determine the occurrence of species substitution. Because the most common type of mislabeling expected was the substitution of Pangasius for Ictalurus spp., products were first tested for the presence of these species using real-time PCR, followed by DNA barcoding for any unidentified samples.

\section{Materials and Methods}

\subsection{Sample collection and preparation}

A total of 80 catfish products were purchased from locations in Orange County, California, from July to August 2016. Forty of the products were purchased from 40 different restaurants and 40 products were purchased fresh/frozen from 39 different retail outlets (i.e., 8 fish markets and 31 grocery stores). All products purchased from grocery stores were subject to COOL. Among the 31 grocery stores visited, 24 were supermarket chains and 7 were singlelocation supermarkets. Among fish markets, 1 was a chain and the other 7 were single-location businesses. Out of the 40 restaurants visited, 13 were chains and 27 were single-location businesses. Only one location was visited for each chain store or restaurant chain included in this study. Details about each sample were recorded, including cooking method, purchase location, advertised name on the label or menu, production method, and country of origin labeling (if available). COOL compliance was assessed by examining the packaging labels for each product, as well as all relevant labeling (e.g., placards, tags, signs, etc.) at the point of sale. Following collection, samples were taken to the laboratory and prepared as described in Wang and Hsieh 
158 (2016), with modifications. Batters, gravies, and sauces were removed from restaurant samples

159 using sterile deionized water. Similarly, fresh and frozen samples were rinsed with sterile

160 deionized water. After rinsing, approximately $5 \mathrm{~g}$ of tissue were removed from the interior of

161 each catfish sample using sterile forceps and scalpels. The $5 \mathrm{~g}$ sample was placed in a sterile 50

$162 \mathrm{~mL}$ Falcon tube (Corning, Corning, NY) and stored at $-80^{\circ} \mathrm{C}$ until DNA extraction.

$163 \quad 2.2$ DNA extraction

164

DNA extraction was performed on tissue samples ( 25 mg) using Qiagen’s DNeasy

165 Blood and Tissue Kit, Spin Column Protocol (Qiagen, Valencia, CA), according to the

166 manufacturer's instructions. DNA was eluted in $50 \mu \mathrm{l}$ Buffer AE preheated to $37^{\circ} \mathrm{C}$. The DNA

167 extract was used immediately for real-time PCR or stored at $-20^{\circ} \mathrm{C}$ for later use. A reagent blank

168 negative control with no sample tissue added was included alongside each set of extracted

169 samples. The DNA concentration was measured using a Thermo Scientific NanoDrop 2000

170 Spectrophotometer (Walham, MA).

1712.3 Real-time PCR

172

A tiered approach was used to identify the species in each catfish sample. First, all

173 samples underwent real-time PCR with the InstantID ${ }^{\mathrm{TM}}$ U.S. Catfish Assay Kit (InstantLabs,

174 Baltimore, MD). This kit tests for the presence of blue catfish (Ictalurus furcatus) or channel

175 catfish (Ictalurus punctatus), with no differentiation between the two species. Any samples that

176 tested negative with the U.S. Catfish Assay were then tested with the InstantID ${ }^{\mathrm{TM}}$ Asian Catfish

177 Assay (InstantLabs). This kit returns a positive result if basa (Pangasius bocourti) or swai

178 (Pangasianodon hypophthalmus) are present, with no differentiation between the two species.

179 Amplification was carried out using a Rotor-Gene® Q Cycler (Qiagen, Germantown, MD) and

180 each reaction tube included $12.5 \mu \mathrm{L} \mathrm{2X}$ Master Mix (InstantLabs) and $12.5 \mu \mathrm{L}$ DNA template 
181 (1.72 $\pm 0.08 \mu \mathrm{g})$. The $2 \mathrm{X}$ Master Mix provided with each kit included an internal control (IC).

182 Each kit also included positive control DNA (undiluted). Two, 10-fold serial dilutions of the 183 positive control $\left(10^{-1}\right.$ and $\left.10^{-2}\right)$ were prepared using molecular-grade water. Each PCR run

184 included the undiluted positive control, the two positive control serial dilutions, and a negative 185 control with no DNA added. Thermocycler settings were followed according to InstantLabs: 95

$186{ }^{\circ} \mathrm{C}$ for $5 \mathrm{~min}$ followed by 35 cycles of $95^{\circ} \mathrm{C}$ for $10 \mathrm{~s}$ and $65^{\circ} \mathrm{C}$ for $30 \mathrm{~s}$. The results were 187 considered positive for a given sample if a cycle threshold (Ct) value was observed for the target 188 signal (FAM) and for the internal control signal (Cy5). The negative control was considered 189 valid if a Ct value was observed for the internal control but not for the target signal. 2.4 DNA-barcoding The single sample that tested negative with both the U.S. Catfish and the Asian Catfish 192 Assay Kits was next tested with DNA barcoding. PCR amplification of a 652-bp region of the 193 cytochrome $c$ oxidase subunit 1 (COI) gene was carried out using the C_FishF1t1-C_FishR1t1 194 primer combination described by Ivanova et al. (2007). This primer combination includes two 195 forward primers, VF2_t1 (5’-

196 TGTAAAACGACGGCCAGTCAACCAACCACAAAGACATTGGCAC-3’) and FishF2_t1 (5’197 TGTAAAACGACGGCCAGTCGACTAATCATAAAGATATCGGCAC-3’), and two reverse 198 primers, FishR2_t1 (5’CAGGAAACAGCTATGACACTTCAGGGTGACCGAAGAATCAGAA-3’) and FR1d_t1 (5’200 CAGGAAACAGCTATGACACCTCAGGGTGTCCGAARAAYCARAA-3’). Each reaction 201 tube included the following: $23 \mu \mathrm{L}$ sterile $\mathrm{H}_{2}$ 0, $25 \mu \mathrm{L}$ HotStar Taq 2 X Master Mix (Qiagen), 0.5 $202 \mu \mathrm{L}$ forward primers $(10 \mu \mathrm{M}), 0.5 \mu \mathrm{L}$ reverse primers $(10 \mu \mathrm{M})$, and $1 \mu \mathrm{L}$ DNA template $(0.12$ $203 \mu \mathrm{g})$. Cycling conditions consisted of: $95^{\circ} \mathrm{C}$ for $15 \mathrm{~min}, 35$ cycles of $94{ }^{\circ} \mathrm{C}$ for $30 \mathrm{~min}, 52{ }^{\circ} \mathrm{C}$ for 
$20440 \mathrm{~s}$, and $72{ }^{\circ} \mathrm{C}$ for $1 \mathrm{~min}$, with a final extension at $72{ }^{\circ} \mathrm{C}$ for $10 \mathrm{~min}$. PCR was carried out with a 205 Mastercycler nexus gradient thermal cycler (Eppendorf, Hauppauge, NY) and a negative control 206 with no DNA added was included in the run.

207 PCR amplicon size and quality were confirmed with an E-Gel iBase Power System (Life 208 Technologies, Carlsbad, CA). The PCR product ( $4 \mu \mathrm{L})$ was loaded with $16 \mu \mathrm{L}$ sterile water onto 209 a pre-cast 1\% agarose E-gel (Life Technologies). The gel was run for $15 \mathrm{~min}$ and the results were 210 captured using Foto/Analyst Express (Fotodyne, Hartland, WI) combined with Transilluminator

211 FBDLT-88 (Fisher Scientific, Waltham, MA) and visualized with PCIMAGE (version 5.0.0.0

212 Fotodyne, Hartland, WI). The PCR product was stored at $-20{ }^{\circ} \mathrm{C}$ until preparation for sequencing.

213 The PCR product was purified using the QIAquick PCR Purification Kit (Qiagen, Valencia, CA)

214 and the sample was shipped to GenScript (Piscataway, NJ) for bi-directional DNA sequencing 215 with the following M13 primers: M13F(-21) (5'-TGTAAAACGACGGCCAGT-3’) and M13R(216 27) (5’-CAGGAAACAGCTATGAC-3’).

\section{$217 \quad 2.5$ Sequencing analysis}

218 Raw sequence data was assembled and trimmed to the COI degenerate bony fish

219 barcoding sequence FISHREF08a (Handy et al. 2011) using Geneious R7 (Biomatters Ltd., 220 Auckland, New Zealand). This sequence was identified to the species level using the Barcode of 221 Life Database (BOLD), Species Level Barcodes Records option, with a species-level cut off of $\geq$ $22298 \%$ genetic similarity. The common name for the identified species was determined using the 223 FDA's Guide to Acceptable Market Names for Seafood sold in Interstate Commerce (FDA 224 2016).

$225 \quad 2.6$ Follow-up testing 
Establishments that were found to have products mislabeled based on species were re-

227 visited approximately one year following the initial collection. If the same product type was

228 available, it was purchased and re-tested for species mislabeling using the tiered approach

229 described above.

230 3. Results and Discussion

$231 \quad 3.1$ DNA-based test results

232 Out of the 80 samples collected, 73 were found to contain Ictaluridae species (Table 1).

233 Initially, 72 of the samples tested positive for Ictaluridae species with real-time PCR. Seven of 234 the eight samples that tested negative for Ictaluridae were found to be positive for Pangasiidae 235 species through real-time PCR. The target signal Ct values for the positive controls used in the 236 U.S. Catfish and Asian Catfish real-time PCR assays ranged from 24.07 (undiluted) to 34.69

237 (1:100 dilution) whereas the target signal Ct values for samples ranged from 18.25 to 32.48. The 238 average U.S. Catfish Ct values across the different sample types ranged from 20.83 for the one 239 steamed sample that tested positive with this kit to $22.74 \pm 1.74$ for pan-fried samples. The 240 sample that tested negative with both assays was a dish of grilled catfish purchased at a 241 restaurant. DNA barcoding analysis of this sample resulted in a single forward sequence read 242 that was 535 bp in length and had 14.4\% high quality bases. This sequence was identified as 243 channel catfish with a genetic similarity of 99.1\%. However, the DNA sequence did not meet the 244 quality parameters established by Handy et al. (2011) for DNA barcoding of fish for regulatory 245 purposes, which state that single sequence reads must have $\geq 98 \%$ high quality bases. After 246 repeating DNA extraction and real-time PCR on this sample, it tested positive for Ictaluridae, in 247 agreement with the sequencing results.

$248 \quad 3.2$ Species mislabeling 
Overall, 7 of the 80 products (9\%) tested in the current study were determined to be

250

251

252

253

254

255

256

257

258

259

260

261

262

263

264

265

266

267

268

269

270 mislabeled with regard to species (Table 1). All seven mislabeled products were purchased from different locations and were found to contain Pangasiidae species in place of Ictaluridae species. As noted in the Introduction, products labeled as catfish that are sold in the United States can only contain species from the Ictaluridae family. Among the mislabeled restaurant dishes, one was purchased from a local restaurant chain and four were purchased from single-location businesses. The two mislabeled fresh/frozen products were purchased from seafood counters at two different ethnic chain stores. Interestingly, the rate of species mislabeling among restaurant dishes (12.5\%) was higher than that found for fresh/frozen fish samples (5\%). This is in agreement with the notion that fish with a higher degree of processing are more susceptible to food fraud (Stiles et al. 2011). Along these lines, deep-fried fish were the most common restaurant dish found to be mislabeled, with 4 of 22 deep-fried samples found to contain Pangasiidae instead of Ictaluridae. Two of the fraudulent dishes were labeled as "fried catfish basket,” one was labeled as "spicy catfish,” and another was labeled as "fried catfish.” Species mislabeling was also detected in one steamed product labeled as "garlic catfish.” Interestingly, deep-fried and steamed catfish were, on average, the least expensive restaurant dishes. These dishes had average prices of US\$13 each, ranging from US\$7.49 to US\$20.47 for deep-fried dishes and US\$12.00-US\$13.99 for steamed dishes. None of the pan-fried, grilled, or baked products was found to be mislabeled on the basis of species. The baked samples were the most highly valued, with an average price of US\$34 \pm 13.73 (range: US\$22.00-\$49.14). However, all three baked catfish dishes purchased were sold as whole fish (head and skin on), thereby reducing the potential for species mislabeling. 
In the case of fresh/frozen samples, all nuggets, cuts and whole catfish were found to

272 contain accurate species labeling. The whole catfish products had the head and skin on, thereby

273 exposing morphological indicators including color and barbels and making it more difficult to

274 deceive buyers. On the other hand, 2 of the 18 catfish fillets were found to contain Pangasiidae

275 species. Fillets had the highest average price for fresh/frozen samples, at US\$3.63 \pm 1.27 per 8-

276 oz (266.8-g) serving, compared to <US\$2.00 per 8-oz serving for whole catfish, nuggets, and

277 cuts, indicating species substitution is more common in higher-valued fresh/frozen catfish

278 products. Both mislabeled fillets were purchased from seafood counters at grocery stores. One of

279 the fillets was labeled as “catfish” and the other was labeled "Filette de Pescado" but was

280 verbally declared to be catfish by an employee. The only other sample collected in this study that

281 relied on a verbal declaration only was a sample of grilled catfish that was verified as containing

282 Ictaluridae.

$283 \quad$ Follow-up sampling and testing on the mislabeled catfish products was conducted

284 approximately one year after the initial collection date. The two products sold at grocery stores

285 were no longer available and one of the restaurants that sold mislabeled catfish was permanently

286 closed. The four remaining restaurant samples, consisting of four deep-fried products, were

287 available for recollection and retesting. All four samples were again found to be mislabeled,

288 testing positive for Pangasiidae. These results indicate a recurring problem of species

289 mislabeling at these establishments; however, additional research is required to determine

290 whether the mislabeling is occurring at the restaurant level or earlier in the supply chain.

The species mislabeling rate of $12.5 \%$ for restaurant dishes in the current study is lower

292 than that found by the study conducted by Wang and Hsieh (2016), which reported a mislabeling

293 rate of $27 \%$ for restaurant dishes labeled as catfish in the Southeastern U.S. The study reported 
294 that 4 of 15 catfish dishes tested were identified as Pangasius using enzyme-linked

295 immunosorbent assay (ELISA). In comparison, the market survey conducted by Consumer

296 Reports (2011) in the Northeastern United States reported a catfish mislabeling rate of 14.3\%

297 among a set of 21 products purchased at retail stores and restaurants. Aside from the differences

298 in sample size and geographic location, a possible explanation for the higher mislabeling rates

299 observed in these studies is that they were conducted prior to the release of the final ruling

300 establishing a continuous USDA inspection program for Siluriformes, including catfish (FSIS

301 2015). Prior to the ruling, catfish were under the jurisdiction of the FDA and were not subject to

302 continuous inspection. In comparison, the current study was conducted during the 18-month

303 transitional period between the effective date of the final ruling (March 2016) and full

304 enforcement (September 2017).

305 In contrast to the above studies, a 2012 FDA survey did not find any mislabeling of

306 catfish collected at the wholesale distribution level in California (FDA 2012). The FDA survey

307 analyzed 40 fillets chosen at random from 5 lots of domestic catfish using DNA barcoding. The

308 reduced mislabeling rate found by FDA may explained by differences in the study design, such

309 as sample number and testing at the wholesale vs. retail level.

$310 \quad 3.3$ COOL compliance

311 In addition to species mislabeling, all fresh/frozen catfish products from grocery stores (n

$312=32$ ) were surveyed for compliance with COOL (Table 2). To convey COOL information to

313 consumers, information on the country of origin and production method for each product must be

314 legible and placed in a location that can be read and understood, for example on a placard, sign,

315 sticker, band, or twist tie (AMS 2017a). A total of 19 of the 32 fresh/frozen products (59\%) were

316 missing country of origin information, production method, or both from the label, meaning they 
317 were not compliant with COOL. Among the products purchased from chain store locations, 52\%

318 (13 of 25 products) were not compliant with COOL, while 86\% (6 of 7) products purchased at

319 single-location stores were not COOL compliant. Overall, 9 samples were missing country of

320 origin labeling and 1 sample contained information that was not compliant with COOL. This

321 sample was a whole catfish labeled "Product of Ecuador/Thai/ or China” with no information on

322 the production method. This product tested positive for Ictaluridae species with real-time PCR.

323 While Ictaluridae species are legally imported into the U.S. from other countries, labeling

324 country of origin with “or”, “and/or”, or "may contain” is not acceptable under COOL regulation

325 as specific origin information is not transparent to consumers (Country of Origin Labeling for

326 Fish and Shellfish 2009). The 22 samples that contained country of origin information in

327 compliance with COOL were all labeled as products of the U.S. and tested positive for

328 Ictaluridae species.

329 A greater proportion of fresh/frozen grocery store samples (50\%) was missing

330 information on the production method as compared to those that were non-compliant with

331 country of origin information (31\%) (Table 2). All 16 samples that did include production

332 method listed "farm-raised" on the label. As shown in Fig. 1, catfish nuggets had the highest rate

333 (57\%, 4 of 7 samples) of labeling both country of origin and method of production, making these

334 the most COOL-compliant catfish product. Catfish fillets had the second highest rate (50\%, 7 of

33514 samples) of COOL compliance, and had the most diversity in terms of labeling, with samples

336 ranging from listing no COOL information to country of origin only, production method only, or

337 both. Whole catfish products were found to be the least compliant with COOL, as only 1 of 8

338 samples (12.5\%) contained both country of origin and method of production on the label. Fillets,

339 whole catfish, and cuts that were not COOL compliant were more likely to label country of 
340 origin than production method, while nuggets were more likely to label production method.

341 Interestingly, both fillets determined to be mislabeled on the basis of species were also not

342 compliant with COOL. While no production method was given for either, one fillet was labeled

343 as "Product of the U.S." and the other fillet did not contain the country of origin information.

344 Pangasius is not produced in the United States, meaning that the country of origin information

345 was incorrect for the one fillet that listed it.

The percentage of fresh/frozen grocery store samples found to be non-compliant with

347 COOL in this study (59\%) was higher than the overall rate reported by the COOL Division as a

348 result of their 2016 retail surveillance reviews (AMS 2017b). These reviews revealed that 10\%

349 of 17,928 fish and shellfish items sold from 3,087 retail stores in all 50 states were not compliant

350 with COOL (K. Becker, personal communication, June 21, 2017). However, information is not

351 available on individual species, making it difficult to make a direct comparison for catfish

352 mislabeling. Further research is necessary to discern whether the lack of COOL compliance

353 observed in this study is restricted to catfish or is also observed in other fish species sold in this

354 sampling region. Similar to the results of this study, the AMS data revealed that a greater

355 proportion of noncompliant samples were missing production information (55\%) as compared to

356 country of origin (45\%). The percentage of fresh/frozen grocery store samples found to be non-

357 compliant with COOL in this study (59\%) was also high compared to a previous COOL study

358 conducted in Baltimore, MD (Lagasse et al. 2014). Lagasse et al. (2014) reported that only 3.8\%

359 of the 628 fresh/frozen seafood products examined in their study were missing production

360 method and/or country of origin information and an additional $1.9 \%$ of products listed multiple

361 origins. However, these numbers were based on data gathered at eight different retail outlets that

362 were visited approximately four times each. In comparison, the COOL results reported in the 
current study were based on single visits to 31 different retail outlets. Interestingly, all of the 67 catfish samples analyzed by Lagasse et al. 2014 contained both production method and country of origin information, with three of the samples listing multiple origins.

Although fish markets and restaurants are exempt from COOL, they can participate on a voluntary basis. Table 2 shows a summary of COOL compliance for catfish products purchased at these establishments. Among the eight products purchased from fish markets, only two fillets were COOL compliant, listing both country of origin (Product of the U.S.) and production method (farm-raised). Similarly, of the 40 restaurant samples collected, two contained information regarding country of origin (Product of the U.S.) and one included information regarding production method (farm-raised). Additionally, one restaurant sample listed both country of origin (Product of the U.S.) and production method (farm-raised) making it COOL compliant. The six products from fish markets and restaurants that supplied information regarding country of origin were all correctly identified as Ictaluridae species. While no fish market samples were mislabeled in terms of species, the rate of species mislabeling among restaurant samples that did not supply COOL information was 13\%.

\section{Conclusion}

This study revealed mislabeling of catfish products sold in restaurants, grocery stores, and fish markets in Orange County, CA. Despite government regulations to prevent misbranding of food products, it is apparent that some catfish products are mislabeled through species substitution and/or by not labeling country of origin and method of production. Accurate labeling of seafood products is important not only for food safety, economic, and conservation reasons, but also to help consumers make informed buying decisions. The high rate of COOL noncompliance as well as evidence of catfish species substitution observed signify the importance of 
386

387

388

389

390

391

392 continuous monitoring of catfish products for mislabeling. The rapid real-time PCR assay utilized in this study could serve as a useful tool for routine monitoring by regulatory bodies and the seafood industry when testing species authenticity of catfish. Additional market research on catfish mislabeling within the United States is recommended in order to determine steps to reduce species substitution and to improve COOL compliance.

\section{Acknowledgements}

This work was supported by internal funding from Chapman University Schmid College of Science and Technology. The authors would like to thank InstantLabs for generously donating real-time PCR kits. The authors would also like to thank Dr. Kenneth Becker with the USDA's Country of Origin Labeling Program for his review of the paper. These entities were not involved in the design or execution of the study.

\section{References}

AMS. 2017a. Country of Origin Labeling (COOL). [Accessed 2017 July 31] Available from: https://www.ams.usda.gov/rules-regulations/cool.

AMS. 2017b. Country of Origin Labeling Fiscal Year 2016 Retail Compliance Data. [Accessed 2017 July 25] Available from: https://www.ams.usda.gov/sites/default/files/media/2016RetailComplianceData.pdf

Brambilla I, Porto G, Tarozzi A. 2012. Adjusting to trade policy: evidence from U.S. antidumping duties on Vietnamese catfish. The Review of Economics and Statistics 94(1):304-19.

Consumer Reports. 2011. Mystery fish: the label said red snapper, the lab said baloney. Consumer Reports December 76(12): 18-22.

Country of Origin Labeling for Fish and Shellfish, 7 C.F.R. § 60 (2009). 
Country of Origin Marking, 19 C.F.R. § 134.11 (2011)

Delaware Sea Grant. 2017. Seafood Health Facts: Making Smart choices Balancing the Benefits and Risks of Seafood Consumption. [Accessed 2017 April 30] Available from: http://www.seafoodhealthfacts.org/.

DOC. 2003. Notice of Final Antidumping Duty Determination of Sales at Less Than Fair Value and Affirmative Critical Circumstances: Certain Frozen Fish Filler from the Socialist Republic of Vietnam. [Accessed 2017 April 18] Available from: http://enforcement.trade.gov/frn/2003/0306frn/03-15794.txt.

DOJ. 2009. President of Company That Illegally Imported Catfish Sentenced to More Than Five Years in Federal Prisononline. [Accessed 2017 May 26] Available from: https://www.justice.gov/opa/pr/president-company-illegally-imported-catfish-sentencedmore-five-years-federal-prison.

DOJ. 2010. CEO of Seafood Importer Pleads Guilty to Importing and Selling Falsely Labeled Fish from Vietnamonline. [Accessed 2017 April 17] Available from: https://www.justice.gov/opa/pr/ceo-seafood-importer-pleads-guilty-importing-andselling-falsely-labeled-fish-vietnam.

DOJ. 2011. Seafood Wholesaler Owners Sentenced in Alabama for Selling Falsely Labeled Fish, Smuggling and Misbranding of Seafood Products. [Accessed 2017 April 11] Available from: https://www.justice.gov/opa/pr/seafood-wholesaler-owners-sentenced-alabamaselling-falsely-labeled-fish-smuggling-and.

Duc N. 2010. Applications of econometric model for price impact assessment of antidumping measures and labeling laws on global markets: a case study of Vietnamese striped catfish. Reviews in Aquaculture 2(2):86-101. 
FAO. 2016. The State of World Fisheries and Aquaculture. [Accessed 2017 April 3] Available from: http://www.fao.org/3/a-i5798e.pdf.

FDA. 2012. FY12_CFSAN Sampling for Seafood Species Labeling in Wholesale Seafood. [Accessed on 2017 May 22] Avaialble from: http://www.fda.gov/downloads/Food/GuidanceRegulation/GuidanceDocumentsRegulator yInformation/Seafood/UCM419984.pdf.

FDA. 2016. The Seafood List. [Accessed 2017 May 1] Available from: http://www.accessdata.fda.gov/scripts/fdcc/index.cfm?set=seafoodlist\&sort=SLSN\&orde $\underline{\mathrm{r}=\mathrm{ASC} \& \text { startrow=1\&type=advanced\&search=catfish\%C2\%A4\%C2\%A4\%C2\%A4. }}$

Farm Security and Rural Investment Act of 2002, 21 U.S.C. 321d(a) and 343(t)

Ferraris CJ. 2007. Checklist of catfishes, recent and fossil (Osteichthyes: Siluriformes), and catalogue of siluriform primary types. Auckland, New Zealand: Magnolia Press.

FSIS. 2015. Mandatory Inspection of Fish of the Order Siluriformes and Products Derived From Such Fish, Final Rule (March 1, 2016). Federal Register 80 (231): 75590-630.

FSIS. 2018. Answers to Frequently Asked Questions - Siluriformes Fish and Fish Product. [Accessed 2018 April 4] Available from: https://www.fsis.usda.gov/wps/portal/fsis/topics/inspection/siluriformes/faq-siluriformes Handy SM, Deeds JR, Ivanova NV, Hebert PDN, Hanner RH, Ormos A, Weigt LA, Moore MM, Yancy HF. 2011. A single-laboratory validated method for the generation of DNA barcodes for the identification of fish for regulatory compliance. Journal of AOAC International 94(1):201-10.

Handy SM, Deeds JR, Ivanova NV, Hebert PDN, Hanner RH, Ormos A, . . Y Yancy HF. 2011. Single Laboratory Validated Method for DNA-Barcoding for the Species Identification of 
Fish for FDA Regulatory Compliance. U.S. Food and Drug Administration Standard Operating Procedure. [Accessed 2018 February 21] Available from: http://www.fda.gov/food/foodscienceresearch/dnaseafoodidentification/ucm237391.htm

Hellberg RSR, Morrissey MT. 2011. Advances in DNA-based techniques for the detection of seafood species substitution on the commercial market. JALA 16(4):308-21.

Ivanova NV, Zemlak TS, Hanner RH, Hebert PDN. 2007. Universal primer cocktails for fish DNA barcoding. Molecular Ecology Notes 7(4):544-8.

Lagasse LP, Love DC and Smith KC. 2014. Country-of-origin labeling prior to and at the point of purchase: an exploration of the information environment in Baltimore City grocery stores. Ecol Food Nutr 53:58-80.

Naaum AM, Warner K, Mariani S, Hanner RH, Carolin CD. 2016. The Need for Seafood Authenticity, in: Naaum AM, Hanner RH (Eds.), Seafood Authenticity and Traceability a DNA Based Perspective. Academic Press, San Diego, p. 3-17.

NOAA. 2016a. Fish Watch. U.S. Seafood Facts. [Accessed 2016 July 30] Available from: https://www.fishwatch.gov/sustainable-seafood/the-global-picture.

NOAA. 2016b. Fisheries of the United States, 2015. Lowther A, Liddel M (Eds), National Marine Fisheries Service Office of Science and Technology, Silver Spring, MD.

NOAA. 2017. Seafood Inspection Program. Part 5- U.S. Grading Standards and Procedures for Grading. [Accessed 2017 March 6] Available from: http://www.seafood.nmfs.noaa.gov/pdfs/part_5_grade_standards.pdf.

NOAA. 2018. Commercial Fisheries Statistics: Cumulative Trade Data by Product. [Accessed 2018 April 2] Available from https://www.st.nmfs.noaa.gov/commercialfisheries/foreign-trade/applications/trade-by-product. 
478 Perishable Agricultural Commodities Act of 1930, 7 U.S.C. § 499a.

479 Stiles ML, Lahr H, Lahey W, Shaftel E, Bethel D, Falls J, Hirshfield MF. 2011. Bait and Switch:

480 How Seafood Fraud Hurts Our Oceans, Our Wallets and Our Health. OCEANA Report.

481 [Accessed 2017 July 31] Available from: http://oceana.org/reports/bait-and-switch-how482 seafood-fraud-hurts-our-oceans-our-wallets-and-our-health.

483 Wang D, Hsieh YHP. 2016. The use of imported pangasius fish in local restaurants. Food 484 Control 65:136-42.

485 Warner K, Mustain P, Lowell B, Geren S, Talmage S. 2016. Deceptive Dishes: Seafood Swaps 486 Found Worldwide. OCEANA Report. [Accessed 2018 April 2] Available from

487 http://usa.oceana.org/publications/reports/deceptive-dishes-seafood-swaps-found-

488 worldwide.

489

490

491 
Table 1. Summary of catfish products collected for this study and results of DNA testing.

\begin{tabular}{|c|c|c|c|c|c|c|}
\hline \multicolumn{2}{|l|}{ Product type } & \multirow{2}{*}{$\begin{array}{l}\begin{array}{l}\text { Number of products } \\
\text { collected }\end{array} \\
22 \\
\end{array}$} & \multirow{2}{*}{$\begin{array}{l}\text { Number of products } \\
\text { identified as Ictaluridae } \\
18\end{array}$} & \multirow{2}{*}{$\begin{array}{l}\text { Number of products } \\
\text { identified as Pangasiidae } \\
4\end{array}$} & \multirow{2}{*}{$\begin{array}{l}\begin{array}{l}\text { Average cost } \pm \text { SD } \\
\text { (USD) }^{\mathrm{a}}\end{array} \\
13.45 \pm 3.75\end{array}$} & \multirow{2}{*}{$\begin{array}{l}\text { Price range (USD) }{ }^{\text {a }} \\
7.49-20.47\end{array}$} \\
\hline Restaurant & Deep fried & & & & & \\
\hline & Pan-fried & 7 & 7 & 0 & $16.83 \pm 5.77$ & $10.28-25.75$ \\
\hline & Grilled & 6 & 6 & 0 & $13.51 \pm 2.33$ & $9.67-14.60$ \\
\hline & Baked & 3 & 3 & 0 & $34.38 \pm 13.73$ & $22.00-49.14$ \\
\hline & Steamed & 2 & 1 & 1 & $13.00 \pm 1.41$ & $12.00-13.99$ \\
\hline & Overall & 40 & 35 & 5 & $15.60 \pm 7.36$ & $7.49-49.14$ \\
\hline \multirow{5}{*}{$\begin{array}{l}\text { Fresh/frozen } \\
\text { fish }\end{array}$} & Fillets & 18 & 16 & 2 & $3.63 \pm 1.27$ & $1.75-5.48$ \\
\hline & $\begin{array}{l}\text { Whole fish, } \\
\text { head on }\end{array}$ & 11 & 11 & 0 & $1.69 \pm 0.24$ & $1.50-2.00$ \\
\hline & Nuggets $^{b}$ & 8 & 8 & 0 & $1.52 \pm 0.07$ & $1.50-1.65$ \\
\hline & Cuts $^{\mathrm{c}}$ & 3 & 3 & 0 & $1.62 \pm 0.53$ & $1.25-2.00$ \\
\hline & Overall & 40 & 38 & 2 & $2.47 \pm 1.32$ & $1.50-5.48$ \\
\hline \multicolumn{2}{|c|}{ All products combined } & 80 & 73 & 7 & $11.08 \pm 8.68$ & $1.50-49.14$ \\
\hline
\end{tabular}

${ }^{a}$ Missing price data for nine fillets, seven whole catfish, two nuggets, and one cut. Fresh/frozen prices are expressed as per 8-oz (226.8-g) serving of fish.

${ }^{\mathrm{b}}$ Nuggets are defined as pieces of belly flaps with or without black membrane and weighing not less than $3 / 4$ ounce or 21.3 g (NOAA 2017).

${ }^{\mathrm{c}}$ Cuts are defined as fillet cuts or steaks with or without bone (NOAA 2017). 
Table 2. Summary of COOL noncompliance for catfish products tested in this study, including information on method of production (MOP) and country of origin (COO) declarations. Values are displayed as the number count (percentage of total).

\begin{tabular}{llllll}
\hline $\begin{array}{l}\text { Purchase } \\
\text { location* }\end{array}$ & $\begin{array}{l}\text { Number of } \\
\text { samples }\end{array}$ & COOL noncompliant & $\begin{array}{l}\text { No or incorrect MOP } \\
\text { declaration }\end{array}$ & $\begin{array}{l}\text { No or incorrect COO } \\
\text { declaration }\end{array}$ & $\begin{array}{l}\text { Neither COO or MOP } \\
\text { declared }\end{array}$ \\
\hline Restaurant & $40(50 \%)$ & $39(97.5 \%)$ & $38(95 \%)$ & $37(92.5 \%)$ & $36(90 \%)$ \\
\hline Grocery Store & $32(40 \%)$ & $19(59.4 \%)$ & $16(50 \%)$ & $6(31.3 \%)$ & $6(75 \%)$ \\
\hline Fish Markets & $8(10 \%)$ & $6(75 \%)$ & $6(75 \%)$ & $55(68.8 \%)$ & $49(61.3 \%)$ \\
\hline Total & 80 & $64(80 \%)$ & $61(76.3 \%)$ & & $79 \%)$ \\
\hline
\end{tabular}

*Compliance with COOL is voluntary for restaurants and fish markets 


\section{Figure Captions}

Figure 1. Summary of COOL compliance for fresh/frozen fish samples $(\mathrm{n}=32)$ collected from grocery stores, including information on method of production (MOP) and country of origin (COO) declarations. 


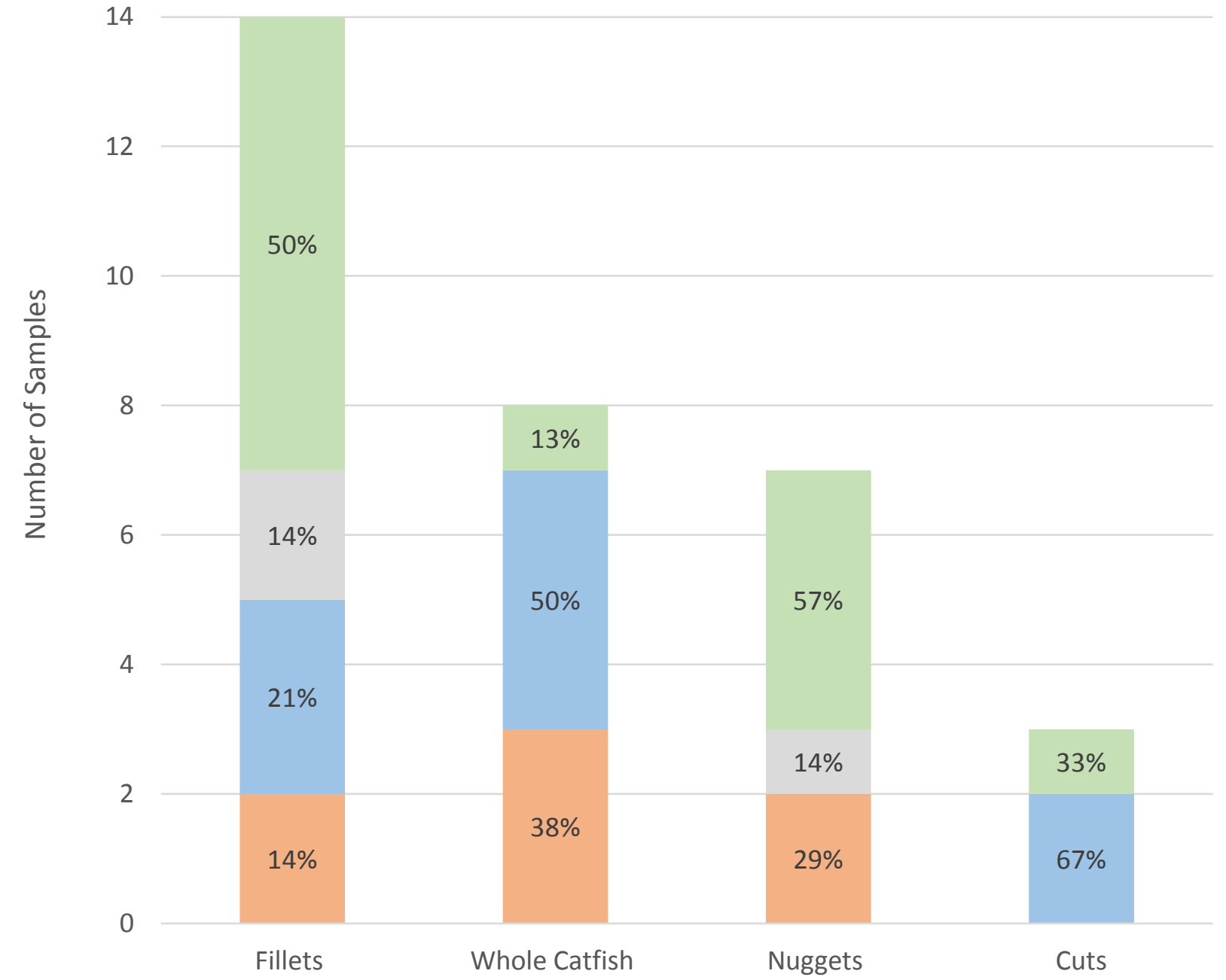

COO and MOP declaration

MOP declaration only

- COO declaration only

No COO or MOP declaration

Sample Type 
Fillets Whole Catfish Nuggets

No COO or MOP declaration

2

COO declaration only

MOP declaration only

COO and MOP declaration

Total

No Country of Origin or Production Method

Country of Origin Only

Production Method Only

Country of Origin and Production Method

Total
3

2

7

14

Fillets

$14 \%$

$21 \%$

$14 \%$

$50 \%$

$100 \%$

32

$4 \quad 0$

$0 \quad 1$

14

$8 \quad 7$

Whole Catfish Nuggets

$38 \% \quad 29 \%$

$50 \% \quad 0 \%$

$0 \% \quad 14 \%$

$13 \% \quad 57 \%$

$100 \% \quad 100 \%$

Fresh/Frozen Samples (Grocery Store)

FIG 1 


\section{Cuts}

0

2

0

1

3

Cuts

$0 \%$

$67 \%$

$0 \%$

$33 \%$

$100 \%$ 